\title{
Narrative Discourse, Memory and the Experience of Travel in W. G. Sebald's Vertigo
}

\author{
Judit PIELDNER
}

\author{
Sapientia Hungarian University of Transylvania (Miercurea Ciuc, Romania) \\ Department of Humanities \\ juditpieldner@yahoo.com
}

\begin{abstract}
Sebald's first prose work, entitled Vertigo (Schwindel. Gefühle., 1990) is perhaps the most intriguing in terms of the absence of clear-cut links between the four narrative segments: "Beyle; or Love is a Madness Most Discrete," “All'estero," "Dr. K Takes the Waters at Riva” and "Il ritorno in patria.” Beyle, i.e. Stendhal, Dr. K, i.e. Kafka, and the first-person narrator of the two quasi-autobiographical parts, are three subjects living in distinct times and places, whose journeys and experiences coalesce into a Sebaldian puzzle to solve, challenging the most varied interpretive terms and discourses, from the Freudian uncanny, through intertextuality (Kristeva) and the indexicality of photography (Barthes, Sontag), to the working of cultural memory (Assmann) and the non-places of what Marc Augé calls hypermodernity. By trying to disclose the discursive strategies of a profoundly elusive and highly complex narrative, the article is aimed at pointing out the rhetorical and textual connections lying at the heart of Sebald's floating way of writing, heralding a vertiginous oeuvre, an unsettling literary journey. ${ }^{1}$
\end{abstract}

Keywords: travel, narrative, intertextuality, memory, photography, nonplaces.

"Is literary greatness still possible? Given the implacable devolution of literary ambition, and the concurrent ascendancy of the tepid, the glib, and the senselessly cruel as normative fictional subjects, what would a noble literary enterprise look like now? One of the few answers available to English-language readers is the work of W. G. Sebald” (Sontag 2009, 41). Susan Sontag's words with which she starts her essay on Sebald, entitled A Mind in Mourning, direct attention to an oeuvre that distinguishes itself by dint of an unmatched profoundness and subtlety, setting against any kind of trend or norm in fiction. Sebald's low but forceful voice as a novelist, memoir writer, essayist, poet and critic - defined

1 This work was created within the framework of a group research project entitled Travel and Cognition, supported by the Sapientia University - Institute of Research Programmes. 
by a penchant for hybrid literary formations, genres and modes of expression testifies to a state of permanent exploration and reflection driven by an impulse of penetrating into the deeper layers of the self and European/human culture. To what extent the three - the self, the European and the universally human - are interconnected is truly attested by his self-imposed exile that is highly similar to that of Joyce, the great predecessor. To be one with one's "uncanny homeland" - with Sebald's own phrasing borrowed from the title of his volume of essays, Unheimliche Heimat (1995) - in emigration, to be at home in homelessness by assuming a distinct geocultural position, provides, paradoxically, the right angle of contemplation and brings the own irrevocably closer to the self.

Sebald found this eminently "distinct" perspective by moving from Germany, through a transitory period in Switzerland, to Norwich, Great Britain, where he became a lecturer at the University of East Anglia and author of an impressively rich and profound literary oeuvre. The East Anglian geocultural landscape, carrying the remnants of the once booming British Empire, was transformed into a literary landscape, into a symbolical terrain of decline, loss and destruction in Sebald's The Rings of Saturn (Die Ringe des Saturn. Eine englische Wallfahrt, 1995). In his 1997 Zürich lectures on Air War and Literature (Luftkrieg und Literatur), published in book form under the title On the Natural History of Destruction (Luftkrieg und Literatur. Mit einem Essay zu Alfred Andersch, 1999), the same East Anglian scenery was connected back to World War II as the place from where the Royal Air Force launched its air raid against the Third Reich, which caused the death of six hundred thousand German civilians and induced a collective trauma that, oddly, was not processed at all, on the contrary, it was almost totally evaded in German literature. Sebald himself assumes the personal responsibility of breaking the silence and unveiling issues repressed into the collective unconscious of the German people - this is what he proposes to carry out in On the Natural History of Destruction, in which he writes: "I grew up with the feeling that something was being kept from me: at home, at school and by the German writers whose books I read hoping to glean more information about the monstrous events in the background of my own life" (Sebald 2002b, 66).

Implicitly, Sebald's entire oeuvre, also including Vertigo (Schwindel. Gefühle., 1990), The Emigrants (Die Ausgewanderten, 1992) and Austerlitz (2001), assumes the task of breaking the silence in the face of collective traumas of the past and redirects attention to Europe's traumatic twentieth century historical heritage, to the mechanisms of erasure of grand history and the working of individual memory. The "Sebald-phenomenon" has reached a large audience and launched an avalanche of critical reflections especially in the English and German language area. Sebald's voice has proved to be capable of stimulating a sense of personal ethical responsibility set against cultic memory and the monstrous machinery of history. The kind of literary archaeology that Sebald pursues preeminently 
makes us rethink the borders between history and representation, text/image and reality, and not least, life and writing.

Sebald's works rely on the gesture of gleaning; Sebald is a great collector, of personal experiences, others' stories and all sorts of visual material that he works into his books. Collecting is essentially linked with writing; as Christina Kraenzle puts it:

A self-described collector, Sebald has noted the importance of collection in his own creative process. As Noam Elcott has observed, collection is also an important structural principle in the prose narratives themselves. Sebald does not so much tell a story, but rather collects and retells other stories, juxtaposing "quotations and commentary, facts and fictions, images and multiple languages [...] without great distinction" so that "Sebald the author vanishes beneath his fabulous miscellany only to reappear as Sebald the collector.” (Kraenzle 2007, 127)

Many of the real and fictitious characters appearing in his books are collectors themselves; thus, an impressive amount of detail, of textual and visual material is accumulated on the pages of Sebald's books, one leading to the other, in boundless series, detours and superimpositions. In this sense, from the perspective of the collected and processed material, his books turn into immense archives, striving to preserve every - even apparently insignificant - item, as if restaging and thus reinstating the role of the institutions of memory (museums, historiography, photography) that came into being in the nineteenth century. Sebald's major concern is memory and the crisis of memory at collective level that characterizes modernity and that can be traced back to the nineteenth century, when the acceleration of the new forms of capitalism brought about the erasure of older patterns. According to prominent Sebald researcher J. J. Long, "[o]ne characteristic of memory crisis is that memory ceases to be a pure matter of consciousness, and comes to reside instead in the very material of our social and psychic life" (2007, 4). Sebald, a researcher himself not only in the academic register but also in his belletristic activity, is particularly interested in the - individual and collective - crisis of memory and in all forms of mnemonic prostheses that emerged to counterpoint the crisis. It is in this respect that the medium of photography becomes significant in the Sebaldian oeuvre, as a possible extension of memory, which also models the working mechanism of memory. In the case of both photography and memory image, the represented/remembered is evoked with the power of "being there" but the act of evocation can never be completed; there is always a rupture, a sense of deferral that hinders the accessibility of the past.

What has been discussed perhaps the most extensively in relation with Sebald's works is the intricate relationship between text and image (Long 2007, Patt and 
Dillbohner 2007, Seale 2013). At Sebald the inserted visual material is never reduced to the mere functions of illustration, documentation or demonstration; the photos apparently underpin the textual information, but at a closer look there is often a sense of displacement between what is said and what is shown, between the referential/factual and the non-referential/fictional. As Lynn L. Wolff remarks, "[o]ntologically tied to an extratextual reality, photographs testify to a past existence, yet Sebald's narratives show that it is only through literature that the documentary nature of photography can be unfolded" $(2014,48)$.

Sebald's first prose work, entitled Vertigo (Schwindel. Gefühle., 1990) is perhaps the most intriguing in terms of the absence of clear-cut links between the four narrative segments: "Beyle; or Love is a Madness Most Discrete," "All'estero," "Dr. K Takes the Waters at Riva" and "Il ritorno in patria." Beyle, i.e. Stendhal, Dr. K, i.e. Kafka, and the first-person narrator of the two quasi-autobiographical parts are three subjects living in distinct times and places, whose journeys and experiences coalesce into a Sebaldian puzzle to solve. Vertigo carries in germ all the motifs to be encountered in the Sebaldian oeuvre, first of all, the motif of travel, in close connection with the issue of memory.

The title of the book, Schwindel. Gefühle in the German original, which has been translated into English as Vertigo, becomes meaningful at several levels: as the particular state of mind of the narrator, a kind of dizziness arising from some personal crisis, the crisis of creation most of the time, as we can read at the beginning of the chapter entitled "All'estero:" "In October 1980 I travelled from England, where I had then been living for nearly twenty-five years in a county which was almost always under grey skies, to Vienna, hoping that a change of place would help me get over a particularly difficult period of my life" $(2000,33)$. This state of mind urges the narrator-protagonist to change place, to travel, which occasions a distinct mode of perception, being simultaneously stuck in the concrete physicality of the journey and dissolved in the wide space of reflection. Further on, "vertigo" indicates the mode of reading pursued by both the narrator-protagonist, who reads the signs with particular sensitivity, and the reader of Sebald's book, who is urged to develop in him/herself a similar skill. Lastly, and perhaps above all, "vertigo" becomes the signifier of the connectedness of all things, the figuration of coincidences and correspondences, a mode of cognition that Sebald reflects on in his essay on Robert Walser, entitled, in the wake of Rousseau, "Le Promeneur Solitaire:" "Slowly I have learnt to understand how everything is connected with everything else across time and space" (Sebald 2014). ${ }^{2}$

Vertigo displays a highly idiosyncratic narrative discourse. The book has a four-part structure, a composition of musical inspiration which can also be encountered in The Emigrants. At first reading, there is little narrative cohesion

2 The essay originally appeared in Sebald's volume of essays entitled A Place in the Country (2013 [1998]). 
among the four parts. The first chapter of Vertigo is centred on the figure of Beyle, alias Stendhal, and on the question of memory. Sebald's text pursues a special kind of performative intertextuality, in the sense that it invites and sort of reactivates a prior text, Stendhal's diary in this case, examining the issue of memory through the filter of the evoked text. As J. J. Long remarks, Sebald is particularly interested in "the question of memory, its relation to the archival practices that characterise modernity, and the kind of subjectivity that is produced by 'archival consciousness'” (2007, 93). Stendhal's diary reflections, mediated by Sebald's text - Sebald is driven by the impulse of multiple mediations - are preoccupied with the nature of memory, with the loss of individual memory, as memory image is profoundly disturbed by - cultural, artistic, even logistical - representations. Sebald investigates in Stendhal's notes those textual places where this experience is reflected on: Stendhal returns to the scene of a traumatic war experience and is surprised to discover that his memories of the Marengo battle scene have been totally replaced by maps and drawings of battle strategy, the visual material functioning as to supersede the trauma experience. This phenomenon can also be interpreted psychoanalytically, in terms of trauma processing: there is always an act of mediation which hinders, as defense mechanism, the full access to the past trauma. A similar moment of loss of authentic memory is revealed in the sculpture of the beloved Méthilde's left hand, cast in plaster, the sight of which stirs strong emotions in the old Stendhal but takes the place of the authentic memory of the lady's hand. Sebald complicates this scheme by examining the relationship between the nineteenth century archival consciousness and its twentieth century aftermath, which also appears in Sebald's last work, Austerlitz. In this novel Sebald positions the scheme into a post-World War II time frame and examines the relationship between photography and film as operators of cultural memory which considerably restructure the working of individual memory. In Vertigo Sebald points at the fact that technologies of reproduction as forms of archiving that precede the twentieth century development of optical media have a similar effect upon the working of individual memory (cf. Long 2007, 94).

The second chapter of Vertigo, entitled "All'estero" - the Italian phrasing meaning, but also linguistically performing, the sense of being "Abroad" - is a quasi-autobiographical account of the narrator-protagonist's journey to European cities, among them Vienna, Venice, Verona and Milan, in the course of which the traveller appears as a twentieth century corollary of Baudelaire's flâneur. Baudelaire's flânerie is related to the experience of rambling in the crowded, anonymous environment of cities that offer a great deal of spectacle, visual attractions in the economically and demographically altered conditions of the nineteenth century. The "visual boom" of the streets (the changing image of the city due to demolition and construction, shopwindows, advertisements, etc.), also complemented by the emergence of new visual media, i.e. photography and 
film, transformed the city into a new spectacle, which led to an altered status of the individual and the observing gaze (cf. Dunajcsik and Nemes 2010). In his famous passage Baudelaire describes this experience as the ecstasy of the spectacle, comparing it to a kaleidoscope reflecting the variegation of life:

The crowd is his element, as the air is that of birds and water of fishes. His passion and his profession are to become one flesh with the crowd. For the perfect flâneur, for the passionate spectator, it is an immense joy to set up house in the heart of the multitude, amid the ebb and flow of movement, in the midst of the fugitive and the infinite. To be away from home and yet to feel oneself everywhere at home; to see the world, to be at the centre of the world, and yet to remain hidden from the world - impartial natures which the tongue can but clumsily define. The spectator is a prince who everywhere rejoices in his incognito. The lover of life makes the whole world his family, just like the lover of the fair sex who builds up his family from all the beautiful women that he has ever found, or that are or are not - to be found; or the lover of pictures who lives in a magical society of dreams painted on canvas. Thus the lover of universal life enters into the crowd as though it were an immense reservoir of electrical energy. Or we might liken him to a mirror as vast as the crowd itself; or to a kaleidoscope gifted with consciousness, responding to each one of its movements and reproducing the multiplicity of life and the flickering grace of all the elements of life. (Baudelaire 1964, 9; emphasis in the original)

The perceiving subject is described as the "I' with an insatiable appetite for the "non-I"" ( Baudelaire 1964, 9). This ecstatic dissolution of the "I" in the "non-I," however, lacks human connections, the individual becomes isolated in the vibration of the metropolis; isolated reflection will lead to the loss of the self. Thus, by the twentieth century the euphoria of Baudelaire's flâneur turns into the cultural shock of the loss of the self, into the sensory disturbance of Rilke's "histerical flâneur" (Dunajcsik and Nemes 2010). In Rilke's only novel, The Notebooks of Malte Laurids Brigge (Die Aufzeichnungen des Malte Laurids Brigge, 1910) - translated into English by the same Michael Hulse who is also the translator of Sebald's Vertigo - the city becomes a space of alienation and homelessness, the discursive terrain of the "I" not rapturously immersed by, but himself becoming the "non-I."

Sebald's aimless urban wanderer in Vertigo is closer to the Rilkean version of the flâneur. He travels by train from one city to another, walks in the streets, stays in cheap hotels, getting in contact with what Marc Augé (1995) calls the non-places of hypermodernity. In Augé's sense of the terms, "[i]f a place can be defined as relational, historical and concerned with identity, then a space which 
cannot be defined as relational, or historical, or concerned with identity will be a non-place” (1995, 77-78). Augé's non-places, distinct from anthropological places, such as airports, hotels, railway and petrol stations, and supermarkets, are places of transit, which do not provide stable patterns of identity, do not play a role in cultural memory, do not dispose of historicity; they only provide the subjects with transitory status, that of travellers, consumers, etc. The Sebaldflâneur, experiencing a state of self-alienation, deliberately seeks these nonplaces, he seems to feel at home in this homelessness. He travels incognito - he feels comfortable under the disguise of a commercial traveller - and in a state of constant anxiety, driven by an impulse of escaping from a state of crisis, but still under the effect of crisis (depression, nervous breakdown), which results in an altered perception and sensitivity.

The narrator-protagonist perceives the city as the space of the uncanny; his perception goes beyond the actual spectacle. Every place reminds the narrator of another space, as if there were some kind of signified behind each visible sign but which is never ultimately attainable. What is more, he perceives the haunting presence of historical and literary figures, e.g. once he has the impression that he has seen Dante among the crowd in Vienna:

On one occasion, in Gonzagagasse, I even thought I recognized the poet Dante, banished from his home town on pain of being burned on the stake. For some considerable time he walked a short distance ahead of me, with the familiar cowl on his head, distinctly taller than the people in the street, yet he passed by them unnoticed. When I walked faster in order to catch him up he went down Heinrichsgasse, but when I reached the corner he was nowhere to be seen. After one or two turns of this kind I began to sense in me a vague apprehension, which manifested itself as a feeling of vertigo. (Sebald 2000,35)

This altered perception turns the cityscape into a space of the uncanny, which is reinforced by the activation of literary intertexts, Franz Kafka's The Trial and Thomas Mann's Death in Venice, as well as painterly references. The memory of the region of Venice occurs to the traveller through the mediation of a painting by Tiepolo, and the text contains the ekphrastic description of the altarpiece St. Thecla Liberating the City of Este from the Plague (1759).

The low-lying cloud drifting in from the Alpine valleys and across that desolated country was conjoined in my mind's eye with a Tiepolo painting which I have often looked at for hours. It shows the plague-ravaged town of Este on the plain, seemingly unscathed. In the background are mountains, and a smoking summit. The light diffused through the picture seems to have 
been painted as if through a veil of ash. One could almost suppose it was this light that drove the people out of the town into the open fields, where, after reeling about for some time, they were finally laid low by the scourge they carried within them. In the centre foreground of the painting lies a mother dead of the plague, her child still alive in her arms. Kneeling to the left is St. Thecla, interceding for the inhabitants of the town, her face upturned to where the heavenly hosts are traversing the aether. Holy Thecla, pray for us, that we may be safely delivered from all contagion and sudden death and most mercifully saved from perdition. Amen. (Sebald 2000, 51)

Here, again, individual memory finds its prosthetic extension in cultural memory, mediated through art, and the spectacle of the here and now turns into a vision extended across historical time.

The third chapter, entitled "Dr. K Takes the Waters at Riva," is centred on the figure of Kafka and reflects Sebald's preoccupation with Kafka's letters and diaries. The Sebaldian text evokes Kafka's visit to Riva in 1913, and describes a state of mind similar to the narrator's, alongside "Kafka's melancholy longing, his Seh(n)nsucht to enter and disappear into the world of images" (Zisselsberger 2007, 291). Markus Zisselsberger points at the interrelatedness of the figure of Kafka and photography in Sebald's thinking, Kafka's famous photo as a child being situated at the root of this connection:

For Sebald, the picture of Kafka epitomizes the epic and affective appeal of a photographic image that links the demand for a narrative with the poetic possibilities afforded to the traveller who follows Kafka's footsteps. As such, the image of Kafka not only illuminates Sebald's understanding of photography but also provides important clues about the narrator's strange immersion in Kafka’s image-world in Vertigo. (2007, 282-283)

Here we can detect the Derridean différance between text and image. Similarly to Sebald's other books, Vertigo is also infused with the uncanny presence of photographs and miscellaneous visual material. Two inserted photos in the third chapter apparently document Kafka's journey, but in fact they only "show" Kafka's absence, e.g. on the two photos that, according to the text, show the inhabitants of Desenzano waiting for Kafka on September 21, but Kafka himself does not turn up (cf. Zisselsberger 2007, 288-293). Thus the illustrative and referential function of the photos is suspended, the Barthesian indexicality of the photos is subverted; instead, there is a relation of indeterminacy between text and image, which characterizes the whole Sebaldian oeuvre. The inserted visual material, and the photos in particular, perform the mediatedness of memory, in that there is always deferral, lack of direct access in the photos; thus, the act of mediation 
performs, both in photography and memory, the infinite regress of the ultimate signified in the Derridean sense.

The fourth chapter, entitled "Il ritorno in patria," relates the Sebald narrator's return to the scene of his childhood, in search of the remnants of a distant past that connects back to post-war Germany. The narrator is in search of the roots of his melancholy nature and sensitivity to decay, which he seems to find in the visual material - paintings, films, family albums, book illustrations - which populated his childhood, as well as in the post-war state of German towns, about which he used to think that decay was their natural state, that they were meant to be so: "and almost every week [in the newsreels] we saw the mountains of rubble in places like Berlin or Hamburg, which for a long time I did not associate with the destruction wrought in the closing years of the war, knowing nothing of it, but considered them a natural condition of all larger cities" (Sebald 2000, 187). The mediated memories of the childhood attest to the experience of belatedness of postmemory (cf. Vees-Gulani 2006, 346). Ultimately, the protagonist of Kafka's short story, The Hunter Gracchus, reveals the literary embeddedness of the narrator's own childhood memories.

There are several links that connect the four parts: the recurrence of dates (September 21, the year 1913), life situations, impressions and melancholy states of mind, as well as recurrent patterns of travel and memory. "What anchors the unstable consciousness of the narrator," Sontag writes, "is the spaciousness and acuity of the details. As travel is the generative principle of mental activity in Sebald's books, moving through space gives a kinetic rush to his marvelous descriptions, especially of landscapes. This is a propelled narrator" (2009, 46). The narrator travels in the wake of literary figures, Stendhal, Kafka, Rilke, who are also travellers. The routes traversed by the narrator often follow routes previously traversed by himself and/or by other - favoured - writers. Thus travelling is performed in its multiple layeredness, that is, in its concrete physicality and as (inter)textual travel, signs, hints, references incessantly alluding to further texts and literary antecedents. This results in the superimposition of routes, states of mind and epiphanies during the journeys.

The manifold constituents of Sebald's style, the richness of detail, the intricate text-image relations, the superimposed intertextual and intermedial layers retain a sense of enigma that calls forth the vertigo of the reading experience. Carsten Strathausen speaks about the "ontological openness" of Sebald's books; Sebald's texts, she says, "never really arrive anywhere, but continue to wander aimlessly in an infinitely expanding, labyrinthine space that defies traditional topography" (2007, 472). In Vertigo, as in Sebald's other works, travelling is performed as a quest, as a "metaphysical search for something that cannot be named or seen” (Strathausen 2007, 475). According to Zoltán András Bán (2010), the unnamable is no other than the past, which is ultimately unexplorable, only 
memory has access to it, but never to the full, it proves insufficient as it implies not reconstruction, but construction.

Sebald's works are characterized by the simultaneous perception of the past and the present; the observing and reflecting gaze always perceives the spectacle of the present in an uncanny interlocking with the haunting vision of the past. His books reveal an intense preoccupation with the past: The Rings of Saturn redraws the patterns of history along the route of the East Anglian "pilgrimage;" The Emigrants evokes private fates and memories; in Austerlitz the protagonist seeks his own past that turns out to be related to the Holocaust. Sebald's obsession with the past and the complexity of the spatio-temporal, cultural, historical and intertextual connections turn his books into "morally accelerated travel narratives" (Sontag 2009, 45).

Space is an activator of memory; the traversed places turn up as points of encounter between individual and cultural memory. What makes Sebald's way of writing especially unique is the superimposition of the own experiences and cultural-textual traces, and their continuous displacement through the medium of images. Consequently, what the narrator experiences is at the same time profoundly personal and the remediation of textual traces, experienced by others, performing travel also as textual travel. This is a special form of intertextuality that Sebald pursues; there is a permanent oscillation between the concrete, physical journey and the textual journey, which can never come to a halt as there is always an urge to seek further correspondences, thus the sense of continuous deferral is inscribed in this narrative pattern. Sebald's works stage the concrete, physical journey as (inter)textual and (inter)medial travel, while the reader, partaking of the testimony of writing, also turns into a traveller - into a flâneur in Sebald's unsettingly enigmatic textual spaces.

\section{Works Cited}

Assmann, Jan. 2011. Cultural Memory and Early Civilization: Writing, Remembrance and Political Imagination. Cambridge: Cambridge University Press.

Augé, Marc. 1995. Non-Places: Introduction to an Anthropology of Supermodernity. Trans. John Howe. London and New York: Verso.

Barthes, Roland. 1981. Camera Lucida. Reflections on Photography. Trans. Richard Howard. New York: Hill and Wang.

Bán, Zoltán András. 2010. "Otthon az inkognitóban - W. G. Sebald: Szédület. Érzés." ["At Home in the Incognito - W. G. Sebald: Vertigo."] Magyar Narancs vol. 22 no. 16 (22 April) http://magyarnarancs.hu/konyv/otthon_az_inkognitoban__W_g_sebald_szedulet_erzes-73617 (Last accessed 9 November 2015) 
Baudelaire, Charles. 1964. The Painter of Modern Life and Other Essays. Trans. and ed. Jonathan Mayne. London: Phaidon.

Dunajcsik, Mátyás and Márió Nemes Z. 2010. "Sebaldia (Megjegyzések a kísérteties urbanitásról W. G. Sebald múveiben)” I. ["Sebaldia (Notes on the Uncanny Urbanity in W. G. Sebald's Works.)”] Múút vol. 55 no. 4.

http://www.muut.hu/korabbilapszamok/020/seb.html. (Last accessed 10 October 2015)

Kafka, Franz. 1946. The Great Wall of China: Stories and Reflections. Trans. Edwin Muir and Willa Muir. New York: Shocken Books.

Kristeva, Julia. 1980. "Word, Dialogue and Novel.” In Desire and Language: A Semiotic Approach to Literature and Art, ed. Leon S. Roudiez, trans. Thomas Gora, Alice Jardine and Leon S. Roudiez, 64-91. New York: Columbia University Press.

Kraenzle, Christina. 2007. "Picturing Place: Travel, Photography and Imaginative Geography in W. G. Sebald's The Rings of Saturn.” In Searching for Sebald, eds. Lise Patt and Christel Dillbohner, 126-145. Los Angeles: The Institute of Cultural Inquiry.

Long, J. J. 2007. W. G. Sebald - Image, Archive, Modernity. Edinburgh: Edinburgh University Press.

Patt, Lise and Christel Dillbohner, eds. 2007. Searching for Sebald. Photography after W. G. Sebald. Los Angeles: The Institute of Cultural Inquiry.

Rilke, Rainer Maria. 2009. The Notebooks of Malte Laurids Brigge. Trans. and ed. Michael Hulse. London: Penguin Books.

Seale, Kirsten. 2013. "Photography, Memory, Metonymy, or W. G. Sebald's Vertigo." TEXT Special Issue 18: Nonfiction Now, eds. David Carlin and Francesca Rendle-Short, October http://www.textjournal.com.au/speciss/ issue18/Seale.pdf (Last accessed 10 March 2016)

Sebald, W. G. 1995. Unheimliche Heimat. Essays zur österreichischen Literatur. [Uncanny Homeland. Essays on Austrian Literature.] Frankfurt am Main: Fischer Taschenbuch Verlag.

Sebald, W. G. 1996. The Emigrants. Trans. Michael Hulse. New York: New Directions Books. [Originally published as Sebald, W. G. 1992. Die Ausgewanderten. Frankfurt am Main: Eichborn AG.]

Sebald, W. G. 2000. Vertigo. Trans. Michael Hulse. New York: New Directions Books. [Originally published as Sebald, W. G. 1990. Schwindel. Gefühle. Frankfurt am Main: Eichborn AG.]

Sebald, W. G. 2001. Austerlitz. Trans. Anthea Bell. London: Hamish Hamilton. [Originally published as Sebald, W. G. 2001. Austerlitz. München: Carl Hanser Verlag.] 
Sebald, W. G. 2002a. The Rings of Saturn. Trans. Michael Hulse. London: Vintage. [Originally published as Sebald, W. G. 1995. Die Ringe des Saturn. Eine englische Wallfahrt. Frankfurt am Main: Eichborn AG.]

Sebald, W. G. 2002b. On the Natural History of Destruction. Trans. Anthea Bell. The New Yorker November 4: 66-77.

Sebald, W. G. 2004. On the Natural History of Destruction. Trans. Anthea Bell. New York: Modern Library. [Originally published as Sebald, W. G. 1999. Luftkrieg und Literatur. Mit einem Essay zu Alfred Andersch. München: Carl Hanser Verlag.]

Sebald, W. G. 2013. A Place in the Country. Trans. Jo Catling. London: Hamish Hamilton. [Originally published as Sebald, W. G. 1998. Logis in einem Landhaus: Über Gottfried Keller, Johann Peter Hebel, Robert Walser und andere. München: Carl Hanser Verlag.]

Sebald, W. G. 2014. "Le Promeneur Solitaire: On Robert Walser." The New Yorker February 6 http://www.newyorker.com/books/page-turner/le-promeneursolitaire-w-g-sebald-on-robert-walser (Last accessed 15 May 2016)

Sontag, Susan. 2009. "A Mind in Mourning." In Where the Stress Falls, 41-48. London: Penguin Books.

Strathausen, Carsten. 2007. "Going Nowhere: Sebald's Rhizomatic Travels.” In Searching for Sebald, eds. Lise Patt and Christel Dillbohner, 472-491. Los Angeles: The Institute of Cultural Inquiry.

Vees-Gulani, Susanne. 2006. "The Experience of Destruction: W. G. Sebald, the Air War, and Literature." In W. G. Sebald. History - Memory - Trauma, eds. Scott Denham and Mark McCulloh, 335-349. Berlin and New York: Walter de Gruyter.

Wolff, Lynn L. 2014. Sebald's Hybrid Poetics. Literature as Historiography. Berlin and Boston: Walter De Gruyter.

Zisselsberger, Markus. 2007. "Melancholy Longings: Sebald, Benjamin and the Image of Kafka." In Searching for Sebald, eds. Lise Patt and Christel Dillbohner, 280-301. Los Angeles: The Institute of Cultural Inquiry. 